\title{
A Supply of Information towards Academic Stress in Students Pursuing Pharmacy Programme in India - An Exploratory Study
}

\author{
Syed Akheel ${ }^{*}$ Magasani Pavan Kumar, Mohanraj Rathinavelu Mudhaliar, Ravindra Reddy. J, \\ Yiragamreddy Padmanabha Reddy
}

Department of Pharmacy Practice, Raghavendra Institute of Pharmaceutical Education and Research-RIPER, Anantapuramu, Andhra Pradesh, INDIA.

\begin{abstract}
Challenging stimulus can lead to positive outcomes such as motivation and improved task performance while threatening ones or distress can result in anxiety, depression and stress. The current prospective observational exploratory study was designed to assess the stressors causing academic stress in pharmacy students of India. In the study a standard stressors scale was designed with 35 questionnaires as open - ended questions to assess both the positive and negative responses of the student participants in a pharmacy institute of Andhra Pradesh. As based on hypothesis of assumption the stressors were categorized as curriculum framework and course of study, faculty and academic learning process, peer evaluation and placement cell and its activities.

The study involved 603 participants out which 253 (42\%) were male and 350 (58\%) were female, the education qualification of the sample 94 were Diploma students, 246 were B. Pharmacy students, 103 were M. Pharmacy students and 160 were Pharm. D students including 20 students of post baccalaureate programme. In our study, the response in pharmacy students towards the stressors was found positive. In conclusion, our study was able to assess certain stressors with a help of a self-developed and administered standard stressors scale, from which the stressor component designed reported a considerable stress in pharmacy students which is negligible in regard to the sample size, but in specific it's the responsibility of the institution and faculty team for early screening and intervention are advisable to limit and minimise the stress.
\end{abstract}

Key words: Academics, Exploratoty study, Pharmacy students, Standard questionnaire, Stress.

\section{INTRODUCTION}

Stressors have a major influence upon mood, our sense of well-being, behaviour, and health. Acute stress responses in young, healthy individuals may be adaptive and typically do not impose a health burden. However, if the threat is unremitting, particularly in older or unhealthy individuals, the long-term effects of stressors can damage health. The relationship between psychosocial stressors and disease is affected by the nature, number, and persistence of the stressors as well as by the individual's biological vulnerability (i.e., genetics, constitutional factors), psychosocial resources, and learned patterns of coping. Psychosocial interventions have proven useful for treating stress-related disorders and may influence the course of chronic diseases. ${ }^{1}$

Noted that the maintenance of life is critically dependent on keeping our internal milieu constant in the face of a changing environment. ${ }^{2}$ Called this "homeostasis. ${ }^{3}$ Used the term "stress" to represent the effects of anything that seriously threatens homeostasis. ${ }^{4}$ The actual or perceived threat to an organism is referred to as the "stressor" and the response to the
Submission Date: 30-08-2016; Revision Date: 17-11-2016; Accepted Date: 23-11-2016

DOI: 10.5530/ijper.51.2.23 Correspondence: Syed Akheel,

Resident - Intern, VI Year Pharm. D Student Department of Pharmacy Practice

Raghavendra Institute of Pharmaceutical Education and Research-RIPER

Anantapuramu, Andhra Pradesh

Ph no: +918121934940 E-mail: moley4u@rediffmail. com

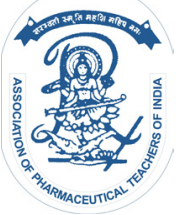

www.ijper.org 
stressor is called the "stress response." Although stress responses evolved as adaptive processes, Selye observed that severe, prolonged stress responses might lead to tissue damage and disease.

A person's response towards stress depends on whether an event is appraised as a challenge or a threat. ${ }^{5}$ Challenging stimulus can lead to positive outcomes such as motivation and improved task performance while threatening ones or distress can result in anxiety, depression, social dysfunction and even suicidal intention. Psychological aspects of stress, is purely dependant on stressors during childhood and adolescence which is associated with negative views toward learning and poor school performance. ${ }^{6}$

Education according to the Western model - is one area that relies on constant stress. There are always targets and deadlines. We spend at least a decade of our lives and sometimes almost two in formal education: a constant round of homework, essays, regular tests, end-ofterm and end-of-year exams - which, it is impressed upon us, will shape our careers and the rest of our lives. Stress is built into the education system. But stress is, by its very nature, intended to be a short-term response to physical danger. Education, by its own very nature, has to be a long term undertaking, the result is inherently a recipe for disaster.In an increasingly pressurised, competitive and market-driven education system, this phenomenon can only become more acute: depression is virtually a built-in hazard. There are several solutions, none of which are mutually exclusive. One is exercise: the stress response prepares us for action, and physical activity helps direct that energy somewhere helpful, reducing cortisol levels and returning the body to its normal state. It is no coincidence that exercise is one of the most powerful antidepressants, too.Secondly, relaxation exercises can help offset the involuntary effects of stress, bringing them to your conscious mind and allowing you put them into context.Lastly, Cognitive Behavioural Therapy (CBT) enables you to examine and adjust the link between the way you think and the way you feel, allowing you to 'switch off' the automatic stress response in situations where it is not strictly warranted.

Stress has become an important topic in academic circles. Many scholars in the field of behavioural science have carried out extensive research on stress and its outcomes and concluded that the topic needed more attention. ${ }^{7}$ Stress in academic institutions can have both positive and negative consequences if not well managed. ${ }^{8}$ Academic institutions have different work settings compared to non-academic and therefore one would expect the difference in symptoms, causes, and con- sequences of stress. ${ }^{9}$ It is important to the society that students should learn and acquire the necessary knowledge and skills that will in turn make them contribute positively to the development of the general economy of any nation. It is important for the institutions to maintain well balanced academic environment conducive for better learning, with the focus on the students' personal needs. Students have different expectations, goals, and values that they want to fulfil, which is only possible if the students' expectations, goals, and values are integrated with that of the institution. ${ }^{10}$ Academic stress among students have long been researched on, and researchers have identified stressors as too many assignments, competitions with other students, failures and poor relationships with other students or lecturers. ${ }^{11}$ Academic stressors include the student's perception of the extensive knowledge base required and the perception of an inadequate time to develop it. ${ }^{12}$ Students report experiencing academic stress at predictable times each semester with the greatest sources of academic stress resulting from taking and studying for exams, grade competition, and the large amount of content to master in a small amount of time. ${ }^{13}$ When stress is perceived negatively or becomes excessive, students experience physical and psychological impairment. Methods to reduce stress by students often include effective time management, social support, positive reappraisal, and engagement in leisure pursuits. ${ }^{14}$ The only scientific research that specifically related leisure satisfaction to academic stress was that of Ragheb and McKinney ${ }^{15}$ who established a negative association between academic stress and leisure satisfaction.

The pressure to perform well in the examination or test and time allocated makes academic environment very stressful. ${ }^{16}$ This is likely to affect the social relations both within the institution and outside which affects the individual person's life in terms of commitment to achieving the goals. ${ }^{[11]}$ Knowing the causes of students stress will make the educational administrator know how to monitor and control the stress factors that are responsible for the students' stress. Often, graduate students perceive that faculty exert great power over their lives and feel that they live in a state of substantial powerlessness. ${ }^{17}$ Another source of stress is the difficulty of achieving social intimacy. It is difficult to find a mate or maintain a relationship with an existing one. Graduate students tend to lack the time and/or the opportunity to develop interpersonal relationships. ${ }^{18}$ Fear of academic failure related to these tasks is a definite stressor. ${ }^{19}$ Thus, stressors affecting students can be categorized as academic, financial, time or health related, and self- imposed. ${ }^{10}$ College students have many obstacles to overcome in 
order to achieve their optimal academic performance. It takes a lot more than just studying to achieve a successful college career. Different stressors such as time management and social activities can all pose their own threat to a student's academic performance.

\section{Stress among pharmacy students}

As the pharmacy education is an important medium that facilitates improvement of patient health outcome and rational use of medications, which is quite evident. Public health interventions, pharmaceutical care, rational medication use and effective medicines supply and management are key components of an accessible, affordable, sustainable and equitable healthcare system which ensures the efficacy, safety and quality of medicines the key role of pharmacy profession. To be effective healthcare team members, pharmacists need skills and attitudes enabling them to assume many different functions, for which WHO (World Health Organization) in association with FIP (International Pharmaceutical Federation) introduced the concept of "seven star pharmacists" by 2000 in its policy statement on Good Pharmacy Education Practice; for a better practice of pharmacy profession and offering optimum best patient care.

The pressure to earn good grades and to earn a degree is very high. ${ }^{20}$ Other potential sources of stress include excessive homework, unclear assignments, and uncomfortable classrooms. ${ }^{21}$ In addition to academic requirements, relations with faculty members and time pressures may also be sources of stress. ${ }^{22}$ Pointed out that the essential factors for the formation of stress are frequent and strong. ${ }^{23}$ There is a related connection between the results of stress and psychological and personality characteristics. Past research found that collegiate stressors included: academics, social relationships, finances, daily hassles (for example, parking and being late) and familial relationships. ${ }^{24}$ Within each domain conflict, insufficient resources, time demands, and new responsibilities had characterized stress. An initial approach in stress management is often an analysis of the stressors, or events that have caused stress. ${ }^{25}$ In this regard, this study tries to identify the sources that resulted in stress for pharmacy students of Anantapuramu District, Andhra Pradesh., India.

\section{MATERIALS AND METHODS}

The prospective observational exploratory study of six months duration (January to June 2015) was carried out in a reputed pharmacy institute of Andhra Pradesh, Raghavendra Institute of Pharmaceutical Education and Research-RIPER, which offers all pharmacy programmes at various degree levels (UG / PG / PhD) affiliated to JNT University Anantapur (JNTUA) and approved by All India Council for Technical Education (AICTE) and Pharmacy Council of India (PCI) under section 12 of Pharmacy Act, New Delhi, India. The study involved all the pharmacy students of the institute, who gave their willingness to participate. Students unwilling to participate were excluded. A Standard validated scale for evaluating the stress was designed by performing an extensive literature survey from the past research studies based on Holmes and Rahe's Social Readjustment Rating Scale (1967), Student Stress Scale (Insel and Roth 1985), University Student Stress developed from Burge's (2009), Organizational Stress Scale (ORS Scale) constructed by Pareek (1993), and the 40 item revised Cope inventory by Zuckerman and Gagne (2003).

Study procedure: The study was performed by designing a standard profoma approved by the Head of Institute and Institutional Review Board (IRB) and data collection was obtained by proper informed consent from the study participants to whom the standards stress scale was distributed. The study was done on three phases.

Phase I: In this phase, the research study was planned by doing an extensive literature survey which is first of its kind, to assess the stressors in pharmacy students for which a profoma including the protocol of the study, base research literatures, standard validated stress scale and students informed consent form were prepared and submitted to the Head of Institute and Institutional Review Board (IRB) for the approval of study.

Phase II: After the authorized signatory of approval, the study was done in four steps, in which each programme students were selected and the validated stress scale was distributed to them twice a month to include majority of students in the study.

Phase III: The results obtained were screened and interpretation was done for the same and it was concluded.

\section{Designing of the standard validated stress scale:} The standard validated stress scale was designed by doing an extensive literature survey and as per suggestions of expertise academicians of the institute by developing certain hypotheses defining the stressors (components of academic stress).

In our study as per the hypotheses of assumption the components of academic stress - stressors are the following: Board of studies - curriculum framework, Faculties and learning process, Peer evaluation and Placement cell activities. 


\section{RESULTS}

The present study involved $603(90 \%)$ students out of 670 pursuing pharmacy education in the institute at various levels during the academic year of 2014 - 2015. Demographic details of the participants involved in the study was categorized based on gender distribution and educational qualification, the results of which were thoroughly analysed and reported in Table 1 (Demographic details of the study participants)
In our study as per the hypotheses of assumption nearly 04 major components of academic stress were designed out of which the primary stressors be Board of studies The curriculum frameworkconcentrating on curriculum content, duration of the programme, duration of course, instructional hours, course of study: number of Subjects, number of working days in academic year, number of Theory / practical / tutorials / library hours, assignments, presentations, slip tests, research studies / projects and examination eligibility criteria (attendance),

\begin{tabular}{|c|c|c|c|c|}
\hline S.no & \multirow{3}{*}{\multicolumn{2}{|c|}{$\begin{array}{c}\text { Demographic details } \\
\text { Gender Distribution } \\
253(42 \%)\end{array}$}} & \multicolumn{2}{|c|}{$\begin{array}{l}\text { Number of students } \\
\qquad(n=603)\end{array}$} \\
\hline \multirow[t]{2}{*}{01} & & & Male & Female \\
\hline & & & 350 (58\%) & \\
\hline \multirow[t]{7}{*}{02} & Educational Qualification & \multirow{2}{*}{$\begin{array}{l}\text { Number of } \\
\text { students }\end{array}$} & \multicolumn{2}{|c|}{ Gender } \\
\hline & & & Male & Female \\
\hline & Diploma in Pharmacy & 94 & 51 & 43 \\
\hline & Degree in Pharmacy & 246 & 94 & 152 \\
\hline & Masters in Pharmacy & 103 & 44 & 59 \\
\hline & Doctor of Pharmacy & 140 & 54 & 86 \\
\hline & $\begin{array}{l}\text { Doctor of Pharmacy } \\
\text { (post baccalaureate) }\end{array}$ & 20 & 10 & 10 \\
\hline
\end{tabular}

\begin{tabular}{|c|c|c|c|c|c|}
\hline \multicolumn{2}{|r|}{ Board of Studies - Curriculum Framework } & \multirow{2}{*}{$\begin{array}{c}\text { Diploma } \\
81 \\
86.17 \%\end{array}$} & \multirow{2}{*}{$\begin{array}{c}\text { Degree } \\
197 \\
80.08 \%\end{array}$} & \multirow{2}{*}{$\begin{array}{c}\text { Pharm.D } \\
112 \\
70 \%\end{array}$} & \multirow{2}{*}{$\begin{array}{c}\text { M.Pharm } \\
90 \\
87.38 \%\end{array}$} \\
\hline 1 & $\begin{array}{l}\text { Do you think the content and depth of curriculum reflects the program } \\
\text { outcome (PO) and program educational objectives (PEO) }\end{array}$ & & & & \\
\hline 2 & Are you satisfied with the duration of programmes & $\begin{array}{c}90 \\
95.74 \%\end{array}$ & $\begin{array}{c}210 \\
85.36 \%\end{array}$ & $\begin{array}{c}110 \\
68.75 \%\end{array}$ & $\begin{array}{c}95 \\
92.23 \%\end{array}$ \\
\hline 3 & $\begin{array}{l}\text { Whether the existing time of each course is enough as per your } \\
\text { scheduled time table }\end{array}$ & $\begin{array}{c}88 \\
93.62 \%\end{array}$ & $\begin{array}{c}225 \\
91.46 \%\end{array}$ & $\begin{array}{c}130 \\
81.25 \%\end{array}$ & $\begin{array}{c}95 \\
92.23 \%\end{array}$ \\
\hline 4 & $\begin{array}{c}\text { Whether the instructional hours of each sessional examinations is } \\
\text { sufficient }\end{array}$ & $\begin{array}{c}84 \\
89.36 \%\end{array}$ & $\begin{array}{c}215 \\
87.39 \%\end{array}$ & $\begin{array}{c}135 \\
84.37 \%\end{array}$ & $\begin{array}{c}90 \\
87.38 \%\end{array}$ \\
\hline \multicolumn{2}{|r|}{ Course of Study } & Diploma & Degree & Pharm.D & M.Pharm \\
\hline 5 & Whether number of subjects (course) per each academic year is ample & $\begin{array}{c}82 \\
87.23 \%\end{array}$ & $\begin{array}{c}185 \\
75.20 \%\end{array}$ & $\begin{array}{c}145 \\
90.62 \%\end{array}$ & $\begin{array}{c}92 \\
89.32 \%\end{array}$ \\
\hline 6 & Number of academic working days satisfies you & $\begin{array}{c}88 \\
93.62 \%\end{array}$ & $\begin{array}{c}180 \\
73.17 \%\end{array}$ & $\begin{array}{l}120 \\
75 \%\end{array}$ & $\begin{array}{c}95 \\
92.23 \%\end{array}$ \\
\hline 7 & $\begin{array}{l}\text { Whether number of theory / practical / tutorial hours defines the course } \\
\text { objectives }\end{array}$ & $\begin{array}{c}84 \\
89.36 \% \\
\end{array}$ & $\begin{array}{c}200 \\
81.30 \%\end{array}$ & $\begin{array}{c}145 \\
90.62 \%\end{array}$ & $\begin{array}{c}90 \\
87.38 \%\end{array}$ \\
\hline 8 & $\begin{array}{l}\text { Are you burdened with excessive assignments, presentations, slip test } \\
\text { and research or project works }\end{array}$ & $\begin{array}{c}80 \\
85.11 \%\end{array}$ & $\begin{array}{c}190 \\
77.23 \%\end{array}$ & $\begin{array}{l}120 \\
75 \%\end{array}$ & $\begin{array}{c}85 \\
82.52 \%\end{array}$ \\
\hline 9 & $\begin{array}{l}\text { Do you think that only academic attendance defines the eligibility } \\
\text { criteria for examinations satisfactorily }\end{array}$ & $\begin{array}{c}80 \\
85.11 \%\end{array}$ & $\begin{array}{c}185 \\
75.20 \%\end{array}$ & $\begin{array}{c}125 \\
78.12 \%\end{array}$ & $\begin{array}{c}90 \\
87.38 \%\end{array}$ \\
\hline 10 & $\begin{array}{l}\text { Are you satisfied with evaluation scheme of the programme in the } \\
\text { institutes }\end{array}$ & $\begin{array}{c}88 \\
93.62 \%\end{array}$ & $\begin{array}{c}200 \\
81.30 \%\end{array}$ & $\begin{array}{c}130 \\
81.25 \%\end{array}$ & $\begin{array}{l}90 \\
87.38 \%\end{array}$ \\
\hline 11 & Do the limit of minimum passing marks satisfies you & $\begin{array}{c}80 \\
85.11 \%\end{array}$ & $\begin{array}{c}185 \\
75.20 \%\end{array}$ & $\begin{array}{c}130 \\
81.25 \%\end{array}$ & $\begin{array}{c}90 \\
87.38 \%\end{array}$ \\
\hline 12 & Eligibility for promotion to next academic year is worth able & $\begin{array}{c}80 \\
85.11 \%\end{array}$ & $\begin{array}{c}180 \\
73.17 \%\end{array}$ & $\begin{array}{c}135 \\
84.37 \%\end{array}$ & $\begin{array}{c}90 \\
87.38 \%\end{array}$ \\
\hline
\end{tabular}


evaluation scheme (awarding of sessional marks), minimum marks for passing and eligibility for promotion to next year, for which the open ended responses received resulted in an exhaustive list of twelve factors that cause stress regarding curriculum and instruction aspect of academic stress, the positive responses of which are given in Table 2 (Positive responses to the curriculum framework by study participants).

Academic achievements of students purely depends on the innovative teaching and learning methodologies, to be developed and upgraded by the academicians, for which the faculties are considered as the centre point of delivery of education. In our study we have taken the secondary stressors as faculty and learning process, as open ended questions for which the positive responses of which are given in Table 3 (Positive responses to the faculty and learning process).
Peer assessment is a tool for student's to evaluate his/ her own success.Peer assessment develops a wide range of skills that can be later transferred to future employment. Peer assessment gives students sense of belonging to the assessment process and foster's their motivation, improves learning, helps students identify their weak and strong points, and encourages students to analyse each other's work, improves self-assessment capabilities and encourages deep, meaningful learning. The positive responses of peer assessment are given in Table 4 (Positive responses to peer assessment).

Placement of the pharmacy students withthe fast growing private sector companies isa recent phenomenon. In fact, many of thestudents join pharmacy programmes with anintention to achieve better placement withgood corporate. Many a timestudents are worried abouttheir future placement.Naturally this worry risesto the level

\begin{tabular}{|c|c|c|c|c|c|}
\hline \multicolumn{2}{|r|}{ Faculties and Academic Learning Process } & Diploma & Degree & Pharm.D & M.Pharm \\
\hline \multirow[t]{7}{*}{13} & \multicolumn{5}{|c|}{ Are you satisfied with the professionalism of the teachers: } \\
\hline & Qualifications & $\begin{array}{c}94 \\
100 \%\end{array}$ & $\begin{array}{c}240 \\
97.56 \%\end{array}$ & $\begin{array}{c}150 \\
93.75 \%\end{array}$ & $\begin{array}{c}95 \\
92.23 \%\end{array}$ \\
\hline & Skills (writing and oral communication) & $\begin{array}{c}85 \\
90.4 \%\end{array}$ & $\begin{array}{c}200 \\
81.33 \%\end{array}$ & $\begin{array}{c}145 \\
90.62 \%\end{array}$ & $\begin{array}{c}93 \\
90.29 \%\end{array}$ \\
\hline & Expertise & $\begin{array}{c}90 \\
95.74 \%\end{array}$ & $\begin{array}{c}200 \\
81.33 \%\end{array}$ & $\begin{array}{c}140 \\
87.5 \%\end{array}$ & $\begin{array}{c}95 \\
92.33 \%\end{array}$ \\
\hline & Specialization & $\begin{array}{c}90 \\
95.74 \%\end{array}$ & $\begin{array}{c}210 \\
85.36 \%\end{array}$ & $\begin{array}{c}130 \\
81.25 \%\end{array}$ & $\begin{array}{c}95 \\
92.33 \%\end{array}$ \\
\hline & Understanding and interaction with students & $\begin{array}{c}80 \\
85.10 \%\end{array}$ & $\begin{array}{c}190 \\
77.23 \%\end{array}$ & $\begin{array}{c}125 \\
78.12 \%\end{array}$ & $\begin{array}{c}90 \\
87.37 \%\end{array}$ \\
\hline & Teaching methodologies & $\begin{array}{c}82 \\
87.23 \%\end{array}$ & $\begin{array}{c}185 \\
75.20 \%\end{array}$ & $\begin{array}{c}130 \\
81.25 \%\end{array}$ & $\begin{array}{c}90 \\
87.37 \%\end{array}$ \\
\hline 14 & $\begin{array}{l}\text { In the institute are you satisfied with the Student Teacher Ratio } \\
\text { (STR) }\end{array}$ & $\begin{array}{c}90 \\
95.74 \%\end{array}$ & $\begin{array}{c}200 \\
81.33 \%\end{array}$ & $\begin{array}{c}135 \\
84.37 \%\end{array}$ & $\begin{array}{c}90 \\
87.37 \%\end{array}$ \\
\hline 15 & Is the eminence of graduate level teaching is best in the institute & $\begin{array}{c}90 \\
95.74 \%\end{array}$ & $\begin{array}{c}200 \\
81.33 \%\end{array}$ & $\begin{array}{c}140 \\
87.5 \%\end{array}$ & $\begin{array}{c}90 \\
87.37 \%\end{array}$ \\
\hline 16 & $\begin{array}{l}\text { Can you rate the quality of academic advising and guidance of } \\
\text { research studies and projects as good in institute }\end{array}$ & $\begin{array}{c}90 \\
95.74 \%\end{array}$ & $\begin{array}{c}200 \\
81.33 \%\end{array}$ & $\begin{array}{c}130 \\
81.25 \%\end{array}$ & $\begin{array}{c}88 \\
85.44 \%\end{array}$ \\
\hline 17 & Are you able to gain a quality standard of exposure & $\begin{array}{c}80 \\
85.10 \%\end{array}$ & $\begin{array}{c}180 \\
73.17 \%\end{array}$ & $\begin{array}{c}145 \\
90.62 \%\end{array}$ & $\begin{array}{c}85 \\
82.52 \%\end{array}$ \\
\hline 18 & $\begin{array}{l}\text { Whether the Mentoring system of the institutes helps you to acquire } \\
\text { more suffice knowledge }\end{array}$ & $\begin{array}{c}80 \\
85.10 \%\end{array}$ & $\begin{array}{c}180 \\
73.17 \%\end{array}$ & $\begin{array}{c}145 \\
90.62 \%\end{array}$ & $\begin{array}{c}85 \\
82.52 \%\end{array}$ \\
\hline
\end{tabular}




\begin{tabular}{|c|c|c|c|c|c|}
\hline \multicolumn{2}{|r|}{ Peer Evaluation } & \multirow{2}{*}{$\begin{array}{c}\text { Diploma } \\
60 \\
63.83 \%\end{array}$} & \multirow{2}{*}{$\begin{array}{c}\text { Degree } \\
240 \\
97.56 \%\end{array}$} & \multirow{2}{*}{$\begin{array}{c}\text { Pharm.D } \\
145 \\
90.62 \%\end{array}$} & \multirow{2}{*}{$\begin{array}{c}\text { M.Pharm } \\
98 \\
95.14 \%\end{array}$} \\
\hline 19 & Are you aware about the objectives of peer evaluation tool & & & & \\
\hline 20 & $\begin{array}{c}\text { Whether the peer evaluation tool assess your quality of work in a } \\
\text { definitive way both qualitatively and quantitatively }\end{array}$ & $\begin{array}{c}50 \\
53.19 \%\end{array}$ & $\begin{array}{c}230 \\
93.49 \%\end{array}$ & $\begin{array}{c}140 \\
87.5 \%\end{array}$ & $\begin{array}{c}93 \\
90.29 \%\end{array}$ \\
\hline 21 & $\begin{array}{l}\text { Whether the timeliness of work is followed and evaluated in the peer } \\
\text { evaluation }\end{array}$ & $\begin{array}{c}60 \\
63.83 \% \\
\end{array}$ & $\begin{array}{c}230 \\
93.49 \%\end{array}$ & $\begin{array}{c}140 \\
87.5 \%\end{array}$ & $\begin{array}{c}93 \\
90.29 \%\end{array}$ \\
\hline 22 & Whether you learn about task support & $\begin{array}{c}50 \\
53.19 \%\end{array}$ & $\begin{array}{c}225 \\
91.46 \%\end{array}$ & $\begin{array}{c}125 \\
78.12 \%\end{array}$ & $\begin{array}{c}90 \\
87.37 \%\end{array}$ \\
\hline 23 & Whether you learn about trouble shooting & $\begin{array}{c}50 \\
53.19 \%\end{array}$ & $\begin{array}{c}225 \\
91.46 \%\end{array}$ & $\begin{array}{c}125 \\
78.12 \%\end{array}$ & $\begin{array}{c}90 \\
87.37 \%\end{array}$ \\
\hline 24 & $\begin{array}{l}\text { Whether the peer evaluation lays a good and meaningful platform for } \\
\text { interaction and sharing of knowledge }\end{array}$ & $\begin{array}{c}50 \\
53.19 \%\end{array}$ & $\begin{array}{c}230 \\
93.49 \%\end{array}$ & $\begin{array}{c}150 \\
93.75 \%\end{array}$ & $\begin{array}{c}98 \\
95.14 \%\end{array}$ \\
\hline 25 & $\begin{array}{l}\text { Do you think the peer evaluation day by day increases your } \\
\text { responsibility and involvement towards allotted work }\end{array}$ & $\begin{array}{c}50 \\
53.19 \% \\
\end{array}$ & $\begin{array}{c}230 \\
93.49 \%\end{array}$ & $\begin{array}{c}150 \\
93.75 \%\end{array}$ & $\begin{array}{c}98 \\
95.14 \%\end{array}$ \\
\hline 26 & $\begin{array}{l}\text { Do the Leadership qualities consistently develops through peer } \\
\text { evaluation }\end{array}$ & $\begin{array}{c}50 \\
53.19 \% \\
\end{array}$ & $\begin{array}{c}225 \\
91.46 \% \\
\end{array}$ & $\begin{array}{c}150 \\
93.75 \% \\
\end{array}$ & $\begin{array}{c}90 \\
87.37 \% \\
\end{array}$ \\
\hline 27 & $\begin{array}{l}\text { Whether the overall performance in peer evaluation rates you as } \\
\text { excellent contributor of teamwork and leadership }\end{array}$ & $\begin{array}{c}50 \\
53.19 \%\end{array}$ & $\begin{array}{c}230 \\
93.49 \%\end{array}$ & $\begin{array}{c}145 \\
90.62 \%\end{array}$ & $\begin{array}{c}90 \\
87.37 \%\end{array}$ \\
\hline
\end{tabular}

\begin{tabular}{|c|c|c|c|c|c|}
\hline \multicolumn{2}{|r|}{ Placement Cell and its Activities } & Diploma & Degree & Pharm.D & M.Pharm \\
\hline 28 & $\begin{array}{l}\text { Does the placement cell demonstrates the conceptual knowledge } \\
\text { related to work }\end{array}$ & $\begin{array}{c}80 \\
85.10 \%\end{array}$ & $\begin{array}{c}196 \\
79.67 \%\end{array}$ & $\begin{array}{c}140 \\
87.5 \%\end{array}$ & $\begin{array}{c}90 \\
87.37 \%\end{array}$ \\
\hline 29 & $\begin{array}{c}\text { Does the placement cell teach you specific technical skills related to } \\
\text { the work being done. }\end{array}$ & $\begin{array}{c}80 \\
85.10 \%\end{array}$ & $\begin{array}{c}196 \\
79.67 \%\end{array}$ & $\begin{array}{c}130 \\
81.25 \%\end{array}$ & $\begin{array}{c}95 \\
92.23 \%\end{array}$ \\
\hline 30 & $\begin{array}{l}\text { Does the placement cell demonstrate understanding by restarting } \\
\text { information's, ideas \& concepts with variety. }\end{array}$ & $\begin{array}{c}80 \\
85.10 \%\end{array}$ & $\begin{array}{c}196 \\
79.67 \%\end{array}$ & $\begin{array}{c}130 \\
81.25 \%\end{array}$ & $\begin{array}{c}90 \\
87.37 \%\end{array}$ \\
\hline 31 & $\begin{array}{l}\text { Does the placement cell evaluate his / her own thinking throughout } \\
\text { the steps \& processes used in problem solving \& decision making. }\end{array}$ & $\begin{array}{c}80 \\
85.10 \%\end{array}$ & $\begin{array}{c}196 \\
79.67 \%\end{array}$ & $\begin{array}{c}125 \\
78.12 \%\end{array}$ & $\begin{array}{c}90 \\
87.37 \%\end{array}$ \\
\hline 32 & $\begin{array}{l}\text { Does the placement cell collects, analyses \& organises relevant } \\
\text { necessary information }\end{array}$ & $\begin{array}{c}75 \\
79.79 \%\end{array}$ & $\begin{array}{c}196 \\
79.67 \%\end{array}$ & $\begin{array}{c}130 \\
81.25 \%\end{array}$ & $\begin{array}{c}85 \\
82.52 \%\end{array}$ \\
\hline 33 & $\begin{array}{l}\text { Through the placement cell do the teamwork: interactions with } \\
\text { others in ways that contributes to effective working relationships \& } \\
\text { achievement of goals is made. }\end{array}$ & $\begin{array}{c}70 \\
74.47 \%\end{array}$ & $\begin{array}{c}180 \\
73.17 \%\end{array}$ & $\begin{array}{c}130 \\
81.25 \%\end{array}$ & $\begin{array}{c}85 \\
82.52 \%\end{array}$ \\
\hline 34 & $\begin{array}{l}\text { Through the placement cell are you able to develop components } \\
\text { like organization and planning, time management, productivity and } \\
\text { adaptability }\end{array}$ & $\begin{array}{c}75 \\
79.79 \%\end{array}$ & $\begin{array}{c}175 \\
71.13 \%\end{array}$ & $\begin{array}{c}140 \\
87.5 \%\end{array}$ & $\begin{array}{c}80 \\
77.67 \%\end{array}$ \\
\hline 35 & $\begin{array}{c}\text { Innovative and creativity strategy are being trained by the placement } \\
\text { cell to meet the market demands }\end{array}$ & $\begin{array}{c}75 \\
79.79 \%\end{array}$ & $\begin{array}{c}180 \\
73.17 \%\end{array}$ & $\begin{array}{c}140 \\
87.5 \%\end{array}$ & $\begin{array}{c}90 \\
87.37 \%\end{array}$ \\
\hline
\end{tabular}

of anxiety andresults in stress amongmany students. Our study also assesses the placement and activities of placement cell as the stressor in pharmacy students, the positive responses of which are given in Table 5 (Positive responses to placement cell and its activities).

\section{DISCUSSION}

To the best of our knowledge, this is a study first of its kind premeditated to explore certain components of stress called stressors in students pursuing pharmacy programme in India towards academics. For which a standard Stressor Scale with four essential components was designed including curriculum frame-work, faculty and academic learning process, students peer participation and evaluation and placements categorized as 35 stressors as questionnaire. In our study, the response in pharmacy students of D. Pharmacy, B. Pharmacy, M. Pharmacy and Doctor of Pharmacy programmes towards the stressors was moderately positive.

Reports of Institute Placement activities suggested that the institute works very hard and more specific in shaping 
the students more competitive with multifaceted expertise and skills as required by the employer. Students of M. Pharmacy programme were on more satisfactory level and of less stress. As the programme objectives and syllabus description of Pharm. D is on portrayal level there was some lacuna of satisfactory levels but students were found more competent with plenty of exposure and multi centric abilities defining no stress towards getting placed. Students of B. Pharmacy and D. Pharmacy were more satisfied towards the preparatory aspects (personality and aptitude development) of placements. Overall, there was negligible amount of stress which be outweighed by students suggestion.

Peer Student Group evaluation report suggested the difference in curriculum and duration of programmes defines the exposure and activities performed by students, as the duration of diploma pharmacy programme is two years the students showed an average satisfactorial response towards the task support and trouble shooting in comparison to the students of other programmes but were optimum to the mark regardless to duration, overall stressors were at considerable level which can be refined to a benefit rank by scrutinizing its limitations. Reports on faculty and academic learning process in the institute was free of stress, as the faculties were more professional and eminent with innovative and expertise teaching abilities, which was at ease of understanding for the students.

Curriculum and instruction form the basis for the academic activity. Any institution or any course cannot fulfil the academic requirements without the predetermined curriculum and structured instruction. Each course has a minimum requirement of instruction hours of the specified curriculum. Hence class work is an integral part of any academic endeavour. There is no substitute for class work in academics. In our study the stress in B. pharmacy and Doctor of pharmacy students were found to be more, the later was due to the 06 years of programme with more curriculum of different speciality and the first was due to semester wise examination pattern covering more subjects within a academic year making it hard to remember the curriculum and the same exists in Doctor of Pharmacy but with nonsemester wise examination structure. Another stressor was attendance and homework's apart from class works. There is no way to escape or avoid and coping with the resultant stress is inevitable. The college academic committee (CAC) has to take initiatives addressing and minimizing these stressors with fostering learning and teaching thoughts within students.

\section{CONCLUSION}

In conclusion, our study was able to assess certain stressors with a help of a self-developed and administered standard stressors scale, from which the stressor component designed reported a considerable stress in pharmacy students which is negligible in regard to the sample size, but in specific it's the responsibility of the institution and faculty team for early screening and intervention are advisable to limit and minimise the stress.

\section{ACKNOWLEDGMENT}

The authors would like to thank the management, staffs and students of Raghavendra Institute of Pharmaceutical Education and Research - RIPER, for their constant support and guidance.

\section{CONFLICT OF INTEREST}

The authors declare No conflict of Interest.

\section{GRANTS / FINANCIAL SUPPORT}

Nil.

\section{ABBREVIATIONS USED}

AICTE: All India Council for Technical Education; B. Pharmacy: Degree in Bachelor of Pharmacy; CAC: College Academic Committee; CBT: Cognitive Behavioural Therapy; D. Pharmacy: Diploma in Pharmacy; FIP: International Pharmaceutical Federation; IRB: Institutional Review Board; JNTUA: Jawaharlal Nehru Technological University Anantapur; M. Pharmacy: Masters in Pharmacy; ORS: Organizational Stress Scale; PCI: Pharmacy Council of India; Pharm. D: Doctor of Pharmacy; PG: Post Graduation; PhD: Doctor of Philosophy; PEO: Program Educational Objectives; PO: Program Outcomes; UG: Under Graduation; WHO: World Health Organization.

\section{REFERENCES}

1. Neil S, Gail I, Scott D. Siegel, STRESS AND HEALTH: Psychological, Behavioural, and Biological Determinants, Annu Rev Clin Psychol. 2005;1:607-28. NIHMSID: NIHMS70622.

2. Bernard C. An Introduction to the study of experimental medicine. Transl. HC Greene. New York: Collier 18651961.

3. Cannon WB. Bodily changes in pain, Hunger, Fear and Rage, 2nd Ed. New York: Appleton 1929.

4. Selye H. The Stress of Life. New York: McGraw-Hill; 1956. PMCid:PMC1823331. 
5. Lowenthal B. The effects of early childhood abuse and the development of resiliency. Early Child Dev. Care: 1998;142(1):43-52. https://doi. org/10.1080/0300443981420105.

6. Lazarus RS, Folkman S. Stress, Appraisal and Coping. New York: Springer. 1984.

7. Agolla JE. Occupational Stress among Police Officers. The case of Botswana Police service, Res. J. Bus. Manage. 2009;2(1):25-35. https://doi. org/10.3923/rjbm.2009.25.35.

8. Stevenson A, Harper S. Workplace stress and the student learning experience, Qual. Assur. Educ. 2006;14(2):167-78. https://doi. org/10.1108/09684880610662042.

9. Chang K, Lu L. Characteristics of organisational culture, stressors and wellbeing: The case of Taiwanese organisations, J. Manage. Psychol. 2007;22(6):549-68. https://doi.org/10.1108/02683940710778431.

10. Goodman ED. How to handle the stress of being a student. Imprint. 1993;40(2):43. PMid:8509109.

11. Fair-brother K, Warn J. Workplace Dimensions, Stress and Job Satisfaction, J.Managerial Psychol. 2003;18(1):8-21. https://doi. org/10.1108/02683940310459565.

12. Carveth JA, Gesse T, Moss N. Survival strategies for nurse-midwiferystudents. Journal of Nurse-Midwifery. 1996;41(1):50-4. https://doi.org/10.1016/00912182(95)00072-0.

13. Abouserie R. Sources and levels of stress in relation to locus of control and self-esteem. 1994.

14. Murphy MC, Archer J. Stressors on the college campus: A comparison of 1985-1993. Journal of College Student Development. 1996;37(1):20-8.

15. Ragheb KG, McKinney J. Campus recreation and perceived academic stress. Journal of College Student Development. 1993;34(1):5-10.

16. Erkutlu HV, Chafra J. Relationship between leadership power bases and job stress of subordinates: example from boutique hotels, Manage. Res. News. 2006;29(5):285-97. https://doi.org/10.1108/01409170610674419.
17. Altbach, Philip G. Commitment and Powerlessness on the American Campus: The Case of the Graduate Student. Liberal Education.1970;56(4):562-82.

18. Hartshorn, Kay. A Day in the Life of a Graduate Student. In Scholars In TheMaking, edited by J. Katz and R. T. Hartnett. Cambridge, MA: Ballinger Publishing Co. 1976.

19. Kolko, David J. Stress Management Techniques for Graduate Students: Cognitive Coping, Problem Solving and Time Management. Paper presented at the annual meeting ofthe South-eastern Psychological Association, March, 1980, Washington, D.C. ED 192 230. 1980.

20. Hirsch JK, Ellis JB. Differences in life stress and reasons for living among college suicide ideators and non-Ideators. College Student Journal. 1996;30:377-84.

21. Kohn JP, Frazer GH. An academic stress scale: Identification and rated importance of academic stressors. Psychological Reports. 1986;59:415-26. https://doi.org/10.2466/pr0.1986.59.2.415.

22. Sgan-Cohen H, Dand LU. Sources of stress among Israeli dental students. The Journal of the American College Health Association. 1988;36(6):317-21. https://doi.org/10.1080/07448481.1988.9939027 PMid:3385090.

23. Piekarska A. School stress, teachers' abusive behaviours, and children's coping strategies. Child Abuse and Neglect. 2000;24(11):1443-9. https://doi. org/10.1016/S0145-2134(00)00201-5.

24. Larson EA. Stress in the Lives of College Women : "Lots to Do and Not Much Time" Journal of Adolescent Research. 2006;21(6):579-606. https:// doi.org/10.1177/0743558406293965.

25. Holmes $\mathrm{TH}$, Rahe $\mathrm{RH}$. The social adjustment rating scale. Journal ofPsychosomatic Research. 1967;11(2):213-8. https://doi.org/10.1016/00223999(67)90010-4.

\section{PICTORIAL ABSTRACT}

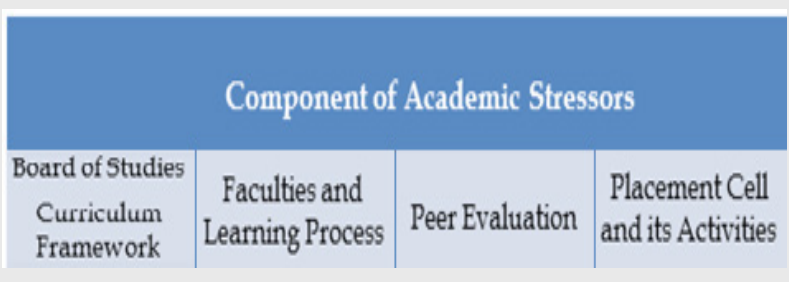

\section{SUMMARY}

- Pharmacy education is an important medium that facilitates improvement of patient health outcome and rational use of medications, which is quite evident.

- There is a related connection between the results of stress and psychological and personality characteristics. Collegiate stressors included: academics, social relationships, finances, daily hassles and familial relationships.

- An initial approach in stress management is often an analysis of the stressors, or events that have caused stress.

- The stressor component designed reported a considerable stress in pharmacy students which is negligible in regard to the sample size, but in specific it's the responsibility of the institution and faculty team for early screening and intervention are advisable to limit and minimize the stress. 


\begin{abstract}
About Authors

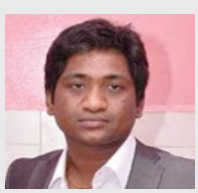

Dr. Mohanraj Rathinavelu: Received his Degree in Bachelor of Pharmacy (2006) and his Doctor of Pharmacy-Post Baccalaureate (2011) in Pharmacy practice from The Tamil Nadu Dr. MGR Medical University, Chennai. He joined the Jawaharlal Nehru Technological University Anantapur, Raghavendra Institute of Pharmaceutical Education \& Research (RIPER) where he teaches courses dealing with professional practice and patient care as Assistant Professor and Academic In-Charge in the department of Pharmacy practice since 2011. Dr. Mohanraj works with both National and International professional bodies of Pharmacy, in policy making of educational reforms and practice for Pharm. D programme in India. He is the Hon. Secretary of Indian Pharmaceutical Association (IPA) Anantapuramu Branch, Secretary and Treasurer of International Society for Pharmacoeconomics and Outcomes Research (ISPOR) - India AP Regional Chapter, and Faculty Advisor of ISPOR RIPER Student Chapter, Member of International Pharmaceutical Federation (FIP), and Life Member of Indian Pharmaceutical Association (IPA).

Syed Akheel: Student of Raghavendra Institute of Pharmaceutical Education and Research - RIPER, pursuing his Doctor of Pharmacy post baccalaureate programme currently practicing his residential internship in RDT Hospitals Bathalapalli, is an active member of ISPOR - India AP Regional Chapter, with a keen research interest on pharmacy education systems and want to make contributions to achieve globalized pharmacy education and practices in coordination with collegiums and groups of the country.
\end{abstract}

Cite this article: Akheel S, Kumar MP, Mudhaliar MR, Ravindra RJ, Reddy YP. A Supply of Information towards Academic Stress in Students Pursuing Pharmacy Programme in India - An Exploratory Study. Indian J of Pharmaceutical Education and Research. 2017;51(2):177-85. 